\title{
Jacek Leociak, Ratowanie. Opowieści Polaków i Żydów, Kraków: Wydawnictwo Literackie, 2010, 313 s.
}

Temat pomocy niesionej przez Polaków skazanym na Zagładę Żydom stanowi ogromne wyzwanie dla badaczy. Po pierwsze, samo zjawisko przybrało w czasie wojny tyle form, że właściwie słowo „pomaganie” wydaje się w tym kontekście homonimem. Pomagano przecież długotrwale, nieraz latami ukrywając prześladowanych we własnym domu, pomocą było też regularne spieniężanie powierzonego przez Żydów majątku i dostarczanie im środków niezbędnych do przeżycia w kryjówce. Istniały też formy pomocy doraźne, okazjonalne, niemal przypadkowe; ktoś poczęstował uciekiniera $z$ getta talerzem zupy, inny podarował mu zniszczone buty. Trzeba jednak pamiętać, że nierzadko od tego talerza zupy czy podartego obuwia zależało życie obdarowanego. Drugi problem dotyczy kwestii gratyfikacji. Niekiedy ratowano zupełnie bezinteresownie, a nawet strona niosąca pomoc wspomagała finansowo podopiecznego. Czasem ukrywany Żyd po prostu płacił rodzaj komornego, którego wysokość mogła być zgodna z ceną obowiązującą na rynku wynajmu mieszkań lub wielokrotnie zawyżona. Zdarzały się też sytuacje szantażu; pod groźbą zaprzestania niesienia pomocy Polacy domagali się bajońskich sum lub żądali zapłaty $\mathrm{w}$ naturze, $\mathrm{w}$ grę wchodziło również wykorzystywanie seksualne. Jakby było mało tych komplikacji, warto jeszcze dodać, że bardzo często relacja pomagający-otrzymujący pomoc miała charakter dynamiczny. Początkowo mogła wynikać z bezinteresownego odruchu serca, by z czasem przekształcić się w bezlitosne wykorzystywanie podopiecznego. Bywało też odwrotnie: Polacy przyjmujący zapłatę za pomoc na wieść o wyczerpaniu zasobów finansowych Żydów nie przestawali nieść ratunku.

Jacek Leociak zdaje sobie doskonale sprawę z zawikłania problematyki, którą podejmuje w książce Ratowanie. Opowieści Polaków i Żydów. Nie proponuje systematycznego ujęcia badanego zagadnienia; nie znajdziemy więc w jego pracy typologii form pomocy, na przykład podziału na pomoc indywidualną i instytucjonalną lub bezinteresowną i gratyfikowaną finansowo. Nie samo doświadczenie ratowania stoi bowiem w centrum zainteresowań Leociaka. Jego książka jest próbą analizy sposobów mówienia o pomocy, a ponieważ bazuje na świadectwach zarówno powstałych w czasie drugiej wojny światowej, jak i pochodzących z końca XX w. - jest to zarazem badanie mechanizmów indywidualnej i zbiorowej pamięci tych, którzy nieśli pomoc i tych, którzy ją otrzymali. To wszystko oczywiście nie oznacza, że nie ma tu mowy o doświadczeniu jako takim, każda badana przez autora historia przecież do niego odsyła.

Większość polskich bohaterów książki Leociaka zasłużyła na tytuł Sprawiedliwego wśród Narodów Świata, nawet jeśli nie każdy z nich formalnie go otrzymał. 
Nie oznacza to jednak, że dzięki niej wkroczymy w rzeczywistość wypełnioną po brzegi altruizmem, miłością bliźniego i bezinteresownym poświęceniem. Jacek Leociak świadom jest tego, że każda opowieść o pomocy Żydom w czasie Holokaustu jest jednocześnie historią niszczenia, zaszczuwania, szantażowania, a w końcu - pozbawiania życia. Heroizm postawy Sprawiedliwych wynika bowiem nie tylko z odwagi przeciwstawienia się nazistowskiemu aparatowi przemocy, lecz także wrogości sąsiadów, krewnych lub członków najbliższej rodziny. Podłoże tej wrogości było rozmaite: zawiść, zazdrość, zemsta, chciwość, antysemicka atmosfera lat przedwojennych, a w końcu wszechogarniający strach, który tłumił ludzkie odruchy. Ten ciemny rewers postawy ratujących jest cały czas obecny w opowieści Leociaka. Warto to podkreślić, ponieważ z polskiego dyskursu o pomaganiu Żydom był on do niedawna starannie wymazywany, co niekiedy przynosiło wręcz absurdalne efekty. Można je dostrzec w największej jak dotychczas polskiej monografii tematu Ten jest z ojczyzny mojej. Polacy z pomoca Żydom 1939-1945. Władysław Bartoszewski i Zofia Lewinówna przytaczają w niej dwa krótkie fragmenty dziennika Zygmunta Klukowskiego. W pierwszym mowa o szczebrzeszyńskim księdzu, który skutecznie interweniuje u Niemców w sprawie kilku skazanych na śmierć Żydów. W drugim fragmencie chodzi o chłopa z pobliskiej wsi, który wraz z rodziną poniósł śmierć za ukrywanie sześciorga Żydów ${ }^{1}$. Tymczasem w eseju Ten jest $z$ ojczyzny mojej, ale go nie lubię... Jan Tomasz Gross przytacza kilkanaście zapisków Klukowskiego, które stanowią wstrząsające świadectwo tego, że Polacy byli nie tylko biernymi świadkami mordu na Żydach, ale również jego aktywnymi uczestnikami, niekiedy wręcz „wolontariuszami Zagłady” - jak to określa Barbara Engelking w swojej ostatniej książce ${ }^{3}$. Każdy, kto czytał dziennik szczebrzeszyńskiego lekarza i społecznika, nie będzie miał wątpliwości, że bardziej nadaje się on na dowód w sprawie podejmowanej przez Grossa niż na egzemplifikację opowieści o polskich Sprawiedliwych ${ }^{4}$.

Jacek Leociak kieruje w swojej książce snop światła na tych, którzy pomoc świadczyli, oraz tych, którzy ją przyjmowali, ale nie gasi go, gdy w badanych historiach pojawiają się postawy ukazujące ciemną stronę stosunków polsko-żydowskich podczas wojny. Przywołuje zarówno polską, jak i żydowską perspektywę, nie próbując w buchalteryjny sposób zachować proporcji między nimi. Chwilami dominuje więc głos jednej lub drugiej strony, co zwykle wynika z charakteru źródła, jakim dysponuje badacz. Korzysta on przede wszystkim ze zgromadzonego w Żydowskim

${ }^{1}$ Ten jest z ojczyzny mojej. Polacy z pomoca Żydom 1939-1945, oprac. Władysław Bartoszewski, Zofia Lewinówna, Warszawa: Świat Książki, 2007, s. 465 i 626.

${ }^{2}$ Jan Tomasz Gross, Ten jest z ojczyzny mojej, ale go nie lubię... [w:] idem, Upiorna dekada. Trzy eseje o stereotypach na temat Żydów, Polaków, Niemców i komunistów 1939-1948, Kraków: Univeritas, 2001.

${ }^{3}$ Barbara Engelking, „Jest taki piękny stoneczny dzień...”. Losy Żydów szukajacych pomocy na wsi polskiej 1942-1945, Warszawa: Stowarzyszenie Centrum Badań nad Zagładą Żydów, 2011.

${ }^{4}$ Zygmunt Klukowski, Zamojszczyzna, t. 1: 1918-1943, Warszawa: Ośrodek Karta, 2008. 
Instytucie Historycznym zespołu „Relacje ocalałych z Zagłady”, koncentrując się na świadectwach powstałych w latach 1945-1967, oraz z wywiadów w formie zapisu audiowizualnego, pochodzących z lat dziewięćdziesiątych XX w. i przechowywanych w USC (University of Southern California) Shoah Foundation Institute for Visual History and Education w Los Angeles.

Niektóre z zagadnień podjętych przez Leociaka nie zostały wcześniej w ogóle dostrzeżone przez innych badaczy. Na przykład analizując zbiór powojennych relacji przechowywanych w Archiwum ŻIH, autor koncentruje się na motywie prośby o pomoc formułowanej przez Polaków, którzy na różne sposoby ratowali Żydów przed Zagładą. Zwykle podkreślają oni bezinteresowność swojej postawy podczas okupacji. Deklarują, że ratowali prześladowanych w poczuciu moralnego obowiązku, kierowali się współczuciem, odruchem sumienia. Jednocześnie w wielu tych relacjach dostrzec można stereotypowy wizerunek Żydów, który nie uległ weryfikacji ani w wyniku wojennych doświadczeń, ani tym bardziej w zetknięciu z kontekstem powojennym. Żydzi niezmiennie pozostają niewdzięczni, skąpi, a jednocześnie bogaci, Polacy zaś - bezinteresowni, szlachetni i ubodzy. Najczęściej to właśnie kłopoty materialne i zdrowotne stanowią bezpośredni impuls do złożenia relacji połączonej z prośbą o wsparcie, która szczególnie w kontekście powojennej biedy wydaje się zrozumiała, mimo że niekiedy opisy dramatycznego położenia, w jakim znajdują się autorzy świadectw, z całą pewnością są przesadzone. Najciekawszym efektem analiz Leociaka jest ukazanie stylistycznej ekwilibrystki, którą obserwować możemy w badanych dokumentach. Nierzadko mają one formę podań, w których toporny styl biurokratyczny miesza się z tonem skargi, lamentacji, błagania, a niekiedy po prostu żądania finansowej rekompensaty za pomoc niesiona podczas wojny. W ciekawy sposób jest też określany adresat tych pism; może nim być Centralny Komitet Żydów w Polsce lub „pan profesor” zatrudniony w ŻIH, albo „Władze Izraelickie” czy „Zarząd Żydowski”. Zdarzają się też wypowiedzi wyrażające zrozumienie dla bezradności ocalałych Żydów, którzy sami będąc w trudnej sytuacji materialnej, nie są w stanie wspomagać swoich niegdysiejszych dobroczyńców.

Na kształt opowieści o ratowaniu Żydów ogromny wpływ ma czas powstania świadectwa i cel, jaki mu przyświeca. Wpływ ten jest tak znaczący, że niekiedy owocuje zupełnie odmiennymi wersjami tej samej historii. Znakomitym przykładem tego zjawiska jest opisana przez Leociaka sprawa Zdzisława i Haliny Krzyczkowskich, którzy ratowali pięcioro Żydów w okupowanej Warszawie między czerwcem 1943 a sierpniem 1944 r. Rada do spraw Sprawiedliwych wśród Narodów Świata przy Yad Vashem w Jerozolimie uhonorowała ich w 1988 r. medalem. Stało się to możliwe dzięki pismu, które jeden z ocalonych przez Krzyczkowskich, Marian Berland, skierował pod koniec 1987 r. do Yad Vashem. Była to forma odpowiedzi na błagalny list, który w tym samym roku Halina Krzyczkowska wysłała do mieszkających w Izraelu dawnych podopiecznych. W hiobowym tonie opisała w nim dramatyczne położenie, w jakim znalazła się wraz z mężem. W poczuciu jawnie deklarowanej wdzięczności za uratowanie życia podczas wojny, Berland 
spisuje świadectwo, w którym, nie wdając się w szczegóły piętnastomiesięcznego ukrywania się w mieszkaniu Krzyczkowskich, przedstawia ich ofiarność i wielkoduszność. Tę wersję opowieści o polskim małżeństwie Leociak konfrontuje w innymi świadectwami: zapisem wywiadu z Marią Berland przeprowadzonego w 1996 r. i przechowywanego w Archiwum USC Shoah Foundation Institute for Visual History and Education, z zapiskami prowadzonymi przez Mariana Berlanda podczas ukrywania się u Krzyczkowskich oraz jego książką wspomnieniową, która w 1958 r. ukazała się po hebrajsku, a w 1992 - w wersji polskiej, zatytułowanej Dni dtugie jak wieki ${ }^{5}$. W tych dokumentach pojawiają się opisy takich aspektów relacji między Krzyczkowskimi a Berlandami, których próżno by szukać zarówno w oficjalnym piśmie do Yad Vashem, jak i w angielskiej oraz polskiej wersji Księgi Sprawiedliwych, gdzie poświęcono im artykuły encyklopedyczne. Opiekunowie Berlandów okazują się bowiem prymitywnymi, nastawionymi na zysk ludźmi marginesu. Wiodącymi rozrywkowe życie, wypełnione suto zakrapianymi imprezami, podczas których ukrywani Żydzi całymi dniami pozbawieni są dostępu do wody i toalety. Gospodarz okazuje się przedwojennym złodziejem, jego żona zaś oszustką, nieustannie okradającą Berlandów z pieniędzy przeznaczonych na żywność. Pomoc świadczona przez Krzyczkowskich jest odpłatna - co zostało przemilczane $\mathrm{w}$ świadectwie skierowanym do Yad Vashem - choć trzeba przyznać, że jak na ówczesne realia nie jest to suma wygórowana. Środki pochodzące od Żydów podnoszą jednak znacznie poziom życia gospodarzy, którzy coraz chętniej sięgają po dobra konsumpcyjne, przede wszystkim po wódkę, co przekłada się na ich większą skłonność do urządzania sobie karczemnych awantur, których mimowolnymi świadkami są Berlandowie. Ci z kolei okazują się na tyle zapobiegliwi, by nie zdradzać opiekunom miejsc, gdzie przechowują pieniądze i inne dobra materialne. Krzyczkowscy wielokrotnie szantażują ich, a nawet dokonują rewizji.

Relacja między Berlandami i Krzyczkowskimi niezmiernie przypomina opisane w dzienniku Calka Perechodnika doświadczenia z okresu, gdy wraz z rodzicami i pewną Żydówką ukrywał się w Warszawie w mieszkaniu „pani Heli”. Tam również jest mowa o pazerności gospodyni, oszukiwaniu na „koszykowym”, jej prymitywnym stylu życia, który jednak dzięki pieniądzom i ubraniom otrzymywanym od podopiecznych zaczął ulegać zmianie. Hela coraz rzadziej urządzała awantury, coraz ładniej się wysławiała i ubierała. Ona również prowadziła z Perechodnikami grę, w której każda ze stron starała się trzymać w szachu tę drugą, bo każda miała coś do stracenia: Hela - źródło utrzymania oraz miłość „Wacia”, kochanka ideowo zaangażowanego w pomoc Żydom, rodzina Calka - w miarę bezpieczne lokum, co w tamtych warunkach mogło oznaczać życie. Autor dziennika, opisując „sadystyczne” - jak je określa - zachowania opiekunki, zauważa jednak: „Ponieważ życia ludzkiego nie można wziąć na wagę złota, tym samym płacąc jej nawet wysokie komorne, nie byliśmy bynajmniej skwitowani. Należała się jej od nas dozgonna

\footnotetext{
${ }^{5}$ Marian Berland, Dni dtugie jak wieki, Warszawa: NOWA, 1992.
} 


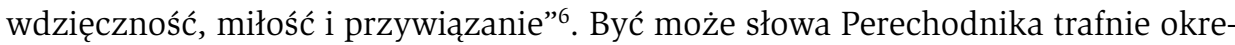
ślają powody, dla których Marian Berland, doskonale pamiętając ciemne strony pomocy Krzyczkowskich, złożył w Yad Vashem pismo, dzięki któremu przyznany został im tytuł Sprawiedliwych wśród Narodów Świata.

Książka Leociaka mówi nie tylko o tym, w jaki sposób ludzie opowiadają o pomocy udzielanej Żydom w obliczu Zagłady, niezależnie od tego, jaki obraz tamtych doświadczeń zapisał się w ich wspomnieniach. Ukazuje również mechanizmy pamięci, dzięki którym uczestnicy tego samego wydarzenia zapamiętują je w zupełnie odmienny sposób. Tego dotyczy historia kilkorga Żydów ukrywających się w budynku klasztoru Sióstr Benedyktynek w Wilnie, przeznaczonym w marcu 1942 r. przez Niemców na filię Archiwum Miejskiego. Leociak uprawia swoistą archeologię pamięci, próbując ułożyć w sensowną całość miejscami całkowicie sprzeczne świadectwa czworga uczestników wydarzeń. Ich opowieści ukazują różne konflikty pamięci, między innymi napięcie między wspomnieniami z dzieciństwa oraz przywoływaniem doświadczeń, które były udziałem dorosłych i w pełni świadomych osób. Jednym z największych walorów książki Leociaka jest właśnie analityczne rozplątywanie węzłów pamięci, wyparcia, zapomnienia i fantazji.

Istotne miejsce w tej książce zajmuje wątek ukrywania Żydów w klasztorach. Zdecydowana większość przywoływanych przez autora żydowskich świadectw ukazuje to doświadczenie jako zanurzenie w enklawie ciszy, spokoju, bezpieczeństwa, pod skrzydłami pełnych dobroci i wyrozumiałości księży oraz sióstr zakonnych. Zapewne tak idylliczny obraz jest $\mathrm{w}$ jakiejś mierze efektem kontrastu z wcześniejszymi etapami życia ukrywających się Żydów, którzy doświadczyli skrajnego głodu, poniżenia, śmierci bliskich i zagrożenia własnego życia. Zarazem jednak te okropne doświadczenia wyczulały na każdy odruch niechęci, pogardy czy wrogości. Opisów takich zachowań opiekunów w sutannach jest zaskakująco mało. Wydaje się to bardzo zastanawiające w kontekście przywołanego przez Leociaka antysemickiego i antyjudaistycznego przekazu, jaki przed wojną płynął do wiernych z prasy katolickiej, periodyków i oczywiście z ambon. Wystarczy zajrzeć choćby do książki Ronalda Modrasa, by przekonać się, że Kościół widział wówczas w Żydzie zaciekłego wroga Polski i katolicyzmu oraz wszelkich wartości moralnych? ${ }^{7}$. Autor Ratowania zwraca uwagę na to, że pomoc świadczona Żydom podczas wojny w klasztorach, z jednej strony będąc realizacją przykazania miłości bliźniego, z drugiej stała w sprzeczności z nauczaniem Kościoła, które w odniesieniu do Żydów zmieniło się dopiero podczas Soboru Watykańskiego II.

Wydaje się, że jeden $\mathrm{z}$ fragmentów wielowątkowej książki Jacka Leociaka może wywołać w czytelniku poczucie niedosytu. Mam na myśli rozdział poświęcony inteligenckim narracjom o ratowaniu Żydów. Autor korzysta w nim z nagrań trzech

\footnotetext{
${ }^{6}$ Calek Perechodnik, Spowiedź. Dzieje rodziny żydowskiej podczas okupacji hitlerowskiej w Polsce, oprac. David Engel, Warszawa: Ośrodek Karta, 2007, s. 191.

${ }^{7}$ Ronald Modras, Kościót i antysemityzm w Polsce w latach 1933-1939, tłum. Witold Turopolski, Kraków: Homini, 2004.
} 
wywiadów znajdujących się w zbiorach Archiwum USC Shoah Foundation Institute for Visual History and Education. Udzielili ich Sprawiedliwi wśród Narodów Świata: Krzysztof Dunin-Wąsowicz, Stanisław Frybes i Jerzy Koźmiński. Leociak przedstawia najpierw ich wojenne losy, a następnie opisuje typ narracji, który wyłania się z każdego z tych wywiadów. Wyróżnia trzy typy: narrację profesjonalną, gawędziarską i powieściową. Niedosyt wynika $z$ tego, że przedstawia je opisowo, zbyt rzadko dopuszczając do głosu samych opowiadających. A chciałoby się przeczytać reprezentatywne dla każdego typu fragmenty opowieści, przede wszystkim posmakować narracji gawędziarskiej i powieściowej. Oczywiście, wymagałoby to również rekonstrukcji pozawerbalnego aspektu komunikacji, stanowiącego integralną część przekazu. Z kolei niewątpliwym atutem tego rozdziału są opisywane przez Leociaka zmagania świadków z osobami przeprowadzającymi wywiad. Bywa, że ich intencje są sprzeczne, zdający relację nie spełnia oczekiwań badacza, który próbuje tak pokierować strumień relacji, by płynął on w stronę wyznaczoną przez przygotowany wcześniej kwestionariusz pytań.

Na koniec dwie dobre nowiny dla czytelników nie od dziś zainteresowanych tematyką poruszaną w tej publikacji. Po pierwsze, autor nie podaje szacunkowych ani tym bardziej precyzyjnych danych liczbowych na temat polskiej pomocy Żydom i nie wikła się tym samym w buchalteryjne rozważania o heroizmie. Po drugie, w książce Ratowanie. Opowieści Polaków i Żydów nie znajdziemy nieustannie wbijanej nam do głowy informacji o tym, że w Ogrodzie Sprawiedliwych Yad Vashem najwięcej drzewek zasadzili Polacy. 